\title{
Metamorphic evolution of the Juiz de Fora Complex: Rhyacian and Ediacaran granulite facies metamorphism records two supercontinent amalgamation events
}

\author{
KATHRYN CUTTS, LUCAS EDUARDO DE ABREU \\ BARBOSA ARAUJO, TALITTA NUNES MANOEL, \\ MONICA HEILBRON AND CLAUDIO VALERIANO
}

Rio de Janeiro State University

Presenting Author: kathryn.cutts@gmail.com

The Juiz de Fora Complex (JFC) is one of several Paleoproterozoic arc terranes that occurs southeast of the southern São Francisco Craton. The JFC together with the Mantiqueira and Piedade complexes, and the Mineiro Belt separate the Archean São Francisco Craton from the Brasiliano orogenic belts. The Paleoproterozoic (2.4-2.1 Ga) Juiz de Fora Complex consists of juvenile, arc-related metaigneous rocks that were extensively deformed and imbricated with overlying Neoproterozoic cover successions of the Andrelândia Group. The entire complex was metamorphosed at granulite facies during the Brasiliano metamorphic event $(620-570 \mathrm{Ma})^{[1]}$. Previous work in the adjacent Mantiqueira and Piedade Complexes indicate that a granulite facies event occurred in these terranes at ca. $2050 \mathrm{Ma}$ during the Minas accretionary orogeny ${ }^{[2,3,4]}$. This orogeny has been inferred to result from the collision between the São Francisco Craton and the Piedade/Mantiqueira continental arc with the juvenile Juiz de Fora intra-oceanic arc. Rocks of the Piedade/Mantiqueira complexes record peak metamorphic conditions of 4-6 kbar and $800{ }^{\circ} \mathrm{C}$ with an amphibolite facies overprint attributed to the Brasiliano orogeny ${ }^{[2]}$. The Juiz de Fora Complex experienced granulite facies metamorphism during the Brasiliano event, obliterating the earlier record. A recent study ${ }^{[5]}$ found ca. 2050 Ma metamorphic rims in a garnet-bearing mafic granulite. Our study targets the metamorphic evolution of this sample in addition to other JFC samples, and granulite facies metasedimentary rocks from the Andrelândia Group, which only experienced the Brasiliano event, in an effort to decrypt the early record. Results suggest that the JFC experienced conditions of 7$8 \mathrm{kbar}$ and $750{ }^{\circ} \mathrm{C}$ at $2.05 \mathrm{Ga}$ based on mineral chemistry of texturally early garnet. The Brasiliano event in the JFC and Andrelândia samples has peak conditions of 5-6 kbar and 850 ${ }^{\circ} \mathrm{C}$.

These results provide additional detail about Paleoproterozoic plate tectonic processes and allow for a comparison of Paleoprotozoic and Ediacaran supercontinent amalgamation events.

[1] Heilbron et al. (2010) Precambrian Research 178,136-148.

[2] Cutts et al. (2018) Gondwana Research 58, 211-234.

[3] Cutts et al. (2020) Precambrian Research 338, 05567.

[4] Bruno et al. (2021) Gondwana Research 92, 149-171.

[5] Araujo et al. (2021) Precambrian Research, in press. 